\title{
Plasma progesterone levels during pregnancy and pseudo- pregnancy in the hare (Lepus europaeus syriacus)
}

\author{
Maya Stavy, J. Terkel and Fortuna Kohen* \\ Department of Zoology, The George S. Wise Center for Life Sciences, Tel-Aviv University, and \\ * Department of Hormone Research, Weizmann Institute of Science, Rehovoth, Israel
}

\begin{abstract}
Summary. A triphasic pattern of progesterone secretion was observed in female hares sampled throughout pregnancy and pseudopregnancy. After injection of hCG and artificial insemination (Day 1), progesterone values rose to a peak of $41.4 \mathrm{ng} / \mathrm{ml}$ about Day 14, remained at this level, then declined around Day 20 before increasing sharply to maximum levels of $67.7 \mathrm{ng} / \mathrm{ml}$ after midpregnancy (Day 28). Levels remained high for several days, then declined until Day 38, increased again until Day 41, before decreasing towards parturition. Progesterone levels were still high $(37.5 \mathrm{ng} / \mathrm{ml}) 24 \mathrm{~h}$ before parturition. The progesterone pattern during pseudopregnancy closely resembled that observed during the first half of pregnancy: levels rose from Day 2 to a peak at Days 11-18, then declined sharply to baseline levels around Day 22. It is suggested that the control of progesterone secretion might be transferred from the pituitary to the placenta at the beginning of the second half of pregnancy.
\end{abstract}

\section{Introduction}

Hares (genus Lepus) are common mammals, with an almost world-wide distribution (Thenius, 1975), but because of the difficulty in breeding and handling these animals (Hediger, 1948; Puget, 1966; Olier \& Montet, 1972) they have been little studied in the laboratory. Female hares show some degree of masculinization at birth (for references see Stavy, 1976), and we became interested in the endocrinological and behavioural aspects of pregnancy in the European hare (Lepus europaeus) in relation to fetal sexual differentiation of the young. The only information available on progesterone levels during pregnancy in the European hare is from a recent study on superfetation by Caillol \& Martinet (1976); the results, based on 4 individuals, did not reveal a consistent pattern of progesterone secretion during pregnancy. In the present study the pattern of progesterone secretion throughout gestation and pseudopregnancy is described.

\section{Materials and Methods}

\section{Animals}

Female hares, Lepus europaeus syriacus, collected in the field as leverets at an average age of 5 days, were hand-reared and kept singly or in pairs in large outdoor pens with a floor area of $1 \times 2 \mathrm{~m}$ (see Puget, 1970). Rabbit pellets, hay and water were always available; fresh carrots were given twice a week. A mineral supplement (Audevard, Limoges Cedex, France) was added to the water.

The hares were used in the present study when they were 9 months to 2 years old. Natural mating in hares usually requires the continual presence of a familiar male for every female, because introduction of an alien male results in vigorous aggression by the female and often injury of the male. Furthermore, the exact timing of conception in these circumstances is not known. To overcome both of these difficulties artificial insemination was used, permitting control over the timing and synchronization of pregnancies. Spermatozoa were obtained from the epididymides of a male anaesthetized with sodium pentobarbital ( $32 \mathrm{mg} / \mathrm{kg}$ : Diamond Laboratories, U.S.A.) and were diluted with physiological saline $(0 \cdot 15 \mathrm{M}-\mathrm{NaCl})$ to a final volume of $5 \mathrm{ml}$. The diluted sperm suspension was stored 
at $4^{\circ} \mathrm{C}$ and used within $1 \mathrm{~h}$. Sperm motility was checked by microscopic observation before and after storage. The sperm suspension from each epididymis was sufficient to inseminate 5 females. Ovulation was induced by the intravenous injection of 50 i.u. hCG (Chorigon: Ikapharm, Ramat-Gan, Israel). Immediately after the hCG injection about $0.5 \mathrm{ml}$ sperm suspension was introduced through a glass tube of $0.3 \mathrm{~mm}$ diameter directly into the vagina (for details see Stavy, Terkel \& Marder, 1978). Pseudopregnant females were those which received an injection of 50 i.u. hCG but were inseminated with $0.5 \mathrm{ml} 0.15 \mathrm{M}-\mathrm{NaCl}$ solution only. The day of insemination or sham insemination was considered Day 1 of pregnancy or pseudopregnancy respectively.

\section{Ovariectomy}

To determine whether the ovary is essential during the second half of pregnancy, 3 does were bilaterally ovariectomized on Day 29 of pregnancy and 3 other does were subjected to sham operation at the same time. Each doe was anaesthetized by intravenous injection of sodium pentobarbital ( $32 \mathrm{mg} / \mathrm{kg}$ ) and the presence of viable fetuses was ascertained by laparotomy before ovariectomy.

\section{Blood sampling}

Two people were required for bleeding: one restrained the hare, sitting with the animal across his knees, while the second person obtained the blood. Blood was collected from the ear vein into a heparinized $5 \mathrm{ml}$ syringe by using a 23-gauge needle. Blood samples were taken from 17 females throughout pregnancy and 6 females throughout pseudopregnancy; 3 of the females were bled during pregnancy and pseudopregnancy. The first blood sample was taken just before the hCG injection. Each pregnant animal was bled at 1- to 5-day intervals throughout gestation, usually between 10:00 and 13:00 h. The most frequent samples were obtained between Days 35 and 39, when the incidence of new pregnancies is highest. Pseudopregnant females were bled once every 5 days at the same time of day as the pregnant females. The blood was centrifuged $(3000 \mathrm{~g})$ at room temperature for $10 \mathrm{~min}$ and the plasma stored at $-20^{\circ} \mathrm{C}$ until assayed.

\section{Progesterone assay}

Plasma progesterone concentrations were measured by the radioimmunoassay procedure described by Lindner \& Bauminger (1974). The antiserum, a generous gift from Professor H. R. Lindner, Department of Hormone Research, Weizmann Institute of Science, was raised in rabbits to progesterone $11 \alpha$-hemisuccinyl-bovine serum albumin. For the determination of procedural losses, $1000 \mathrm{ct} / \mathrm{min}\left[1,2,6,7-{ }^{3} \mathrm{H}\right]$ progesterone (sp. act. $94 \mathrm{Ci} / \mathrm{mmol}$ : Radiochemical Centre, Amersham, U.K.) were added to $0.5 \mathrm{ml}$ plasma and shaken in glass-stoppered conical centrifuge tubes with 20 volumes petroleum ether (b.p. $40-60^{\circ} \mathrm{C}$ ). The tubes were then immersed in a solid $\mathrm{CO}_{2}$-acetone bath to freeze the aqueous phase and the organic phase was decanted into a second tube and dried under nitrogen. The dry eluate was redissolved in distilled acetone (1 or $2 \mathrm{ml})$. A portion of this solution $(0.2$ or $0.4 \mathrm{ml})$ was transferred to a counting vial, and the remainder was used for triplicate assay of progesterone concentration. Aliquots of $50-200 \mu \mathrm{l}$ of the redissolved extract were evaporated under nitrogen. Tris-buffer $(200 \mu \mathrm{l}$ ) containing $2.2 \%$ bovine $\gamma$-globulin (Fraction II, Sigma, St. Louis, Missouri, U.S.A.) was then added to the evaporated standards (progesterone was purchased from Ikapharm, Ramat-Gan, Israel) and samples. Antiserum to progesterone ( $300 \mu \mathrm{l})$ was then added, and the tubes were incubated overnight at $4{ }^{\circ} \mathrm{C}$. Dextran-coated charcoal $(200 \mu \mathrm{l}, 1 \%$ charcoal- $0 \cdot 1 \%$ Dextran T-70) was then used to separate the bound and free fractions. The specificity of the antibody in this system has been described by Kohen, Bauminger \& Lindner (1975): cross-reaction with oestrogens, androgens and corticosteroids was $<0 \cdot 1 \%$, there was a slight cross-reaction with $17 \alpha-$ hydroxyprogesterone $(2 \%)$ and the 11-oxygenated derivatives of progesterone ( $44 \%$ for the $11 \alpha$ hydroxy- and $8 \%$ for $11 \beta$-hydroxyprogesterone).

The lower limit of sensitivity of the assay, calculated as the hormone concentration which corresponded to the lower $95 \%$ confidence limit of the non-hormone containing tubes within each assay, averaged $15 \mathrm{pg}$ progesterone/tube. Intra-assay precision was examined by measuring the progesterone concentration of replicates from a pool of luteal-phase plasma samples of normal women. The mean \pm s.d. progesterone concentration from 10 samples was $14 \cdot 25 \pm 0.45 \mathrm{ng} / \mathrm{ml}$. 
Inter-assay precision was examined by analysis of progesterone concentration from a pool of female serum run on separate days in each assay: in 6 runs, the mean progesterone concentration was $8 \cdot 12 \pm 0.23$ (s.d.) $\mathrm{ng} / \mathrm{ml}$. For estimation of blank values, buffer $(0.5 \mathrm{ml})$ was extracted with petroleum ether ( 20 volumes) and subjected to the radioimmunoassay procedure as described above. The mean progesterone concentration found in the $0.5 \mathrm{ml}$ samples of petroleum ether-extracted buffer examined on separate runs was $10 \pm 7 \mathrm{pg}$.

\section{Results}

The progesterone concentrations before insemination were $<1 \mathrm{ng} / \mathrm{ml}$. The results presented in Textfig. 1 suggest a triphasic pattern of progesterone secretion during pregnancy. In Phase 1, progesterone concentration increased gradually from Days 2-3 and reached a maximum $(41.4 \mathrm{ng} / \mathrm{ml})$ at about Day 14 of pregnancy. These levels were maintained during the 3rd week of pregnancy. Phase 2 began in the 4th week with a rapid rise of progesterone levels, reaching a maximum level $(67 \cdot 7 \mathrm{ng} / \mathrm{ml})$ around Day 28. Progesterone levels then declined to a mean of $37.5 \mathrm{ng} / \mathrm{ml}$ about 1 week before parturition. The maximum levels of progesterone in Phase 2 were about $60 \%$ higher than those observed at the peak of Phase 1. In Phase 3, progesterone levels rose again to a third peak $(55 \mathrm{ng} / \mathrm{ml})$ a few days before parturition. Relatively high progesterone levels $(37.5 \mathrm{ng} / \mathrm{ml})$ were still observed $24 \mathrm{~h}$ before parturition, but on the day after parturition, progesterone had again reached baseline levels $(<1$ $\mathrm{ng} / \mathrm{ml})$.

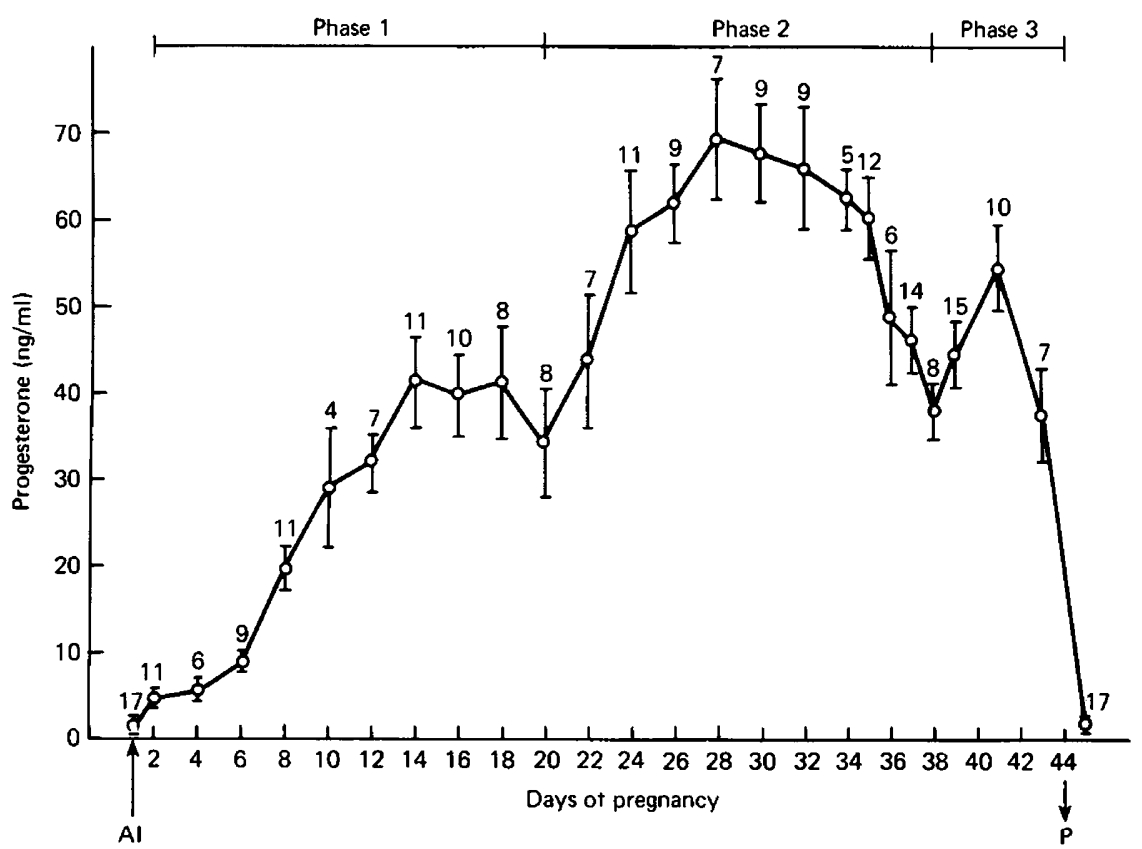

Text-fig. 1. Mean \pm s.e.m. concentrations of progesterone in the peripheral plasma of hares throughout pregnancy. Samples taken at 2-day intervals are combined and plotted on even-numbered days, except for samples on Days 35 to 39 which are plotted at daily intervals. The numbers of hares at each point are indicated. $\mathbf{A I}=$ artificial insemination; $\mathrm{P}=$ parturition.

The general pattern of progesterone secretion during pseudopregnancy resembled that of Phase 1 secretion during pregnancy. Progesterone rose gradually after the induction of pseudopregnancy, reaching a maximum between Days 11 and 18, then declining to baseline levels between Days 20 and 24. In each of the 3 females in which progesterone levels were measured during pregnancy and 
pseudopregnancy, the duration, pattern and amplitude of the hormone levels during Phase 1 of pregnancy were strikingly similar to those observed during her own pseudopregnancy (Text-fig. 2). In each individual, the decline of progesterone to baseline levels at the termination of pseudopregnancy coincided with the progesterone decline at the end of Phase 1.

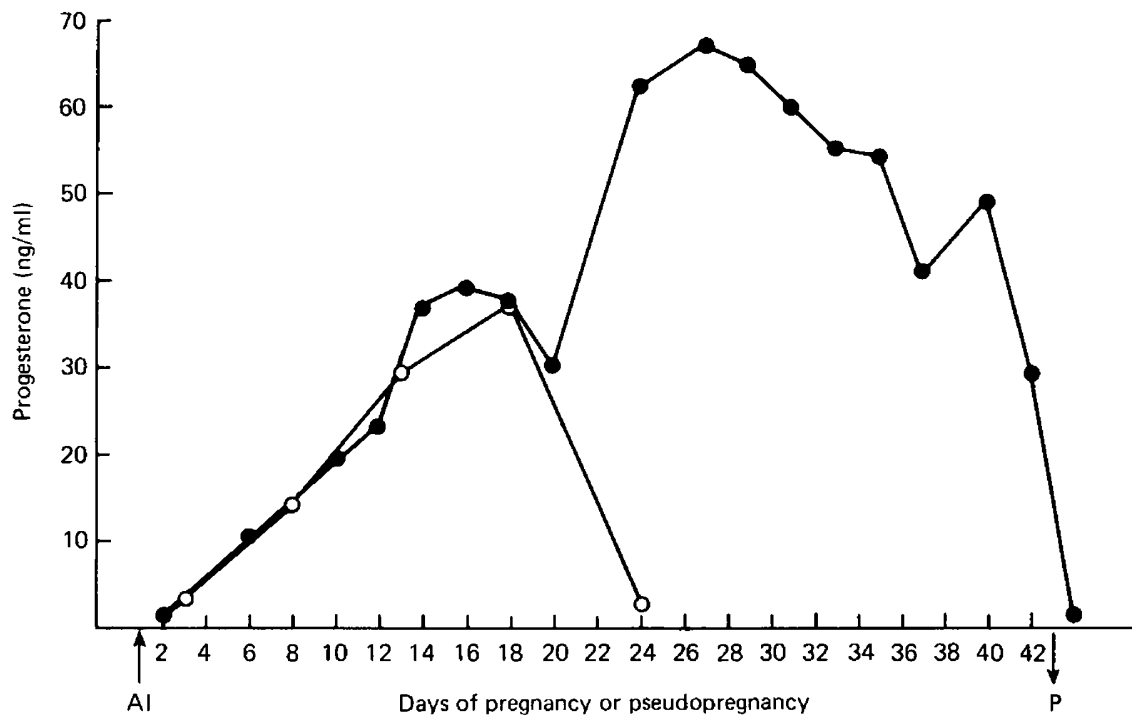

Text-fig. 2. Plasma progesterone concentrations in a single hare (No. 37) illustrating the hormone profile during pregnancy $(\bullet)$ and pseudopregnancy $(O)$. $A I=$ artificial insemination; $P=$ parturition.

The 3 females which were ovariectomized on the 29th day of pregnancy aborted within $36 \mathrm{~h}$. Progesterone levels at this time were less than $1 \mathrm{ng} / \mathrm{ml}$. Two of the sham-operated females gave birth normally, while the third aborted 5 days after the operation. We attribute the abortion of this animal to severe stress, because the abortion occurred shortly after the first bleeding and the animal seemed nervous and upset.

\section{Discussion}

In spite of the individual differences in progesterone levels and the variable interval between blood samples, a common pattern of plasma progesterone levels during pregnancy was observed in all the hares sampled. The pattern is, however, different from that in the rabbit, which is taxonomically the closest living relative of the hare. In the rabbit, progesterone levels rise gradually from the 3rd day of pregnancy, reach peak levels around midpregnancy, and decline gradually toward the end of pregnancy (Mikhail, Noall \& Allen, 1961; Hilliard, Spies \& Sawyer, 1968; Challis, Davies \& Ryan, 1973; Hilliard, Scaramuzzi, Penardi \& Sawyer, 1973). We observed that the pattern of progesterone secretion in the hare resembles that of the rat and mouse. In the latter two species, the pituitary can be removed at any time after midpregnancy without interrupting pregnancy. However, in the rabbit the pituitary is essential throughout pregnancy, hypophysectomy at any stage causing abortion through failure of the corpora lutea (Robson, 1937, 1940; Westman \& Jackobsohn, 1937; Spies, Hilliard \& Sawyer, 1968).

Three lines of evidence suggest that during pregnancy the control of progesterone in the hare is transferred from the pituitary to the placenta at the end of Phase 1 of secretion. (1) The progesterone profile observed during pregnancy in the hare is similar to that found in the rat (Pepe \& Rothchild, 1972; Morishige, Pepe \& Rothchild, 1973) and the mouse (Murr, Stabenfeldt, Bradford \& Geschwind, 1974; Virgo \& Bellward, 1974). The decline of progesterone levels at the end of the first half of pregnancy in these rodents has been shown to be due to the cessation of pituitary control of progesterone secretion, while the placenta has not yet achieved complete steroidogenic control (for a discussion see Murr et al., 1974). (2) The termination of pseudopregnancy in the hare occurs at the 
same time as the end of Phase 1 of progesterone secretion (see Text-fig. 2). It has been shown both in the rat (Pepe \& Rothchild, 1974) and the mouse (Choudary \& Greenwald, 1969; Murr et al., 1974) that the termination of pseudopregnancy coincides with the time at which the pituitary ceases to be the main luteotrophic source and progesterone therefore declines rapidly to basal levels. (3) In the hare, ovariectomy in the second half of pregnancy resulted in immediate abortion, indicating that the ovary remains the main source of progesterone throughout pregnancy (for review see Hilliard, 1973; Ryan, 1973) as in other mammals which abort under the same conditions (rat, rabbit). Thus placental progesterone is either inadequate or absent. It is believed that in the above two species, which cannot maintain pregnancy following ovariectomy, the rise in progesterone during the second half of pregnancy is due to the transfer of control of progesterone secretion from the pituitary to the placenta (as discussed by Murr et al., 1974). Perhaps this is also the case in the hare.

The phenomenon of superfetation is common in the European hare: the animals can mate and conceive up to 7 days before parturition (Hediger, 1948; Martinet, Legouis \& Moret, 1970). In most mammals, high progesterone levels prevent ovulation by blocking LH secretion or by a direct inhibition of the ovaries (Schwartz \& Talley, 1968; Van Rees, Van Dieten, Bijleveld \& Muller, 1968; Beyer \& McDonald, 1973; Labhsetwar, 1975). In many species, exogenous progesterone blocks sexual behaviour during pregnancy; in the rabbit matings do occur during the last few days of pregnancy but the progesterone levels are very low (Beyer \& Rivaud, 1969; Beyer, Vidal \& McDonald, 1969). Because our hares were housed individually, no mating behaviour before parturition was observed. Nevertheless, the drop in progesterone levels just before parturition occurred at the time when the incidence of new pregnancies is highest (Martinet et al., 1970; Caillol \& Martinet, 1976).

We thank the keepers of the Canadian Center of Ecological Zoology for expert management and care of the hare colony, and especially the curator, Mr Uri Marder, whose interest and painstaking assistance in this project made it possible. We also thank $\mathrm{Dr}$ Amelia Terkel for helping in the preparation of the manuscript, Dr Shlomo Hellwing for his critical comments, and Mrs Regie Suzin for preparing the illustrations.

\section{References}

Beyer, C. \& MCDonald, P. (1973) Hormonal control of sexual behaviour in the female rabbit. $A d v$. Reprod. Physiol. 6, 185-219.

Beyer, C. \& Rivaud, N. (1969) Sexual behaviour in pregnant and lactating domestic rabbits. Physiol. Behav. 4, 753-757.

Beyer, C., Vidal, N. \& McDonald, P.G. (1969) Interaction of gonadal steroids and their effect on sexual behaviour in the rabbit. J. Endocr. 45, 407413.

Caillol, M. \& Martinet, L. (1976) Preliminary results on plasma progesterone levels during pregnancy and superfetation in the hare, Lepus europaeus. J. Reprod. Fert. 46, 61-64.

Challis, J.R.G., Davies, I.J. \& Ryan, K.J. (1973) The concentrations of progesterone, estrone and estradiol-17 $\beta$ in the plasma of pregnant rabbits. Endocrinology 93, 971-976.

Choudary, J.B. \& Greenwald, G.S. (1969) Ovarian activity in the intact or hypophysectomized pregnant mouse. Anat. Rec. 163, 359-369.

Hediger, H. (1948) Die Zucht des Feldhasen (Lepus europaeus Pallas) in Gefangeschaft. Physiol. comp. Oecol. 1, 46-62.

Hilliard, J. (1973) Corpus luteum function in guinea pigs, hamsters, rats, mice and rabbits. Biol. Reprod. 8, 203-221.
Hilliard, J., Spies, H.G. \& Sawyer, C.H. (1968) Cholesterol storage and progestin secretion during pregnancy and pseudopregnancy in the rabbit. Endocrinology 82, 157-165.

Hilliard, J., Scaramuzzı, R.J., Penardi, R. \& Sawyer, C.H. (1973) Progesterone, estradiol and testosterone levels in ovarian venous blood of pregnant rabbits. Endocrinology 93, 1235-1238.

Kohen, F., Bauminger, S. \& Lindner, H.R. (1975) Preparation of antigenic steroid-protein conjugator. In Steroid Immunoassay, pp. 11-32. Eds E. H. D. Cameron, S. G. Hillier \& K. Griffiths. Alpha-Omega Publishing Ltd, Cardiff.

Labhsetwar, A.P. (1975) Progesterone: sites of action in inhibiting ovulation in hamsters. J. Reprod. Fert. 42, 341-350.

Lindner, H.R. \& Bauminger, S. (1974) Production and characterization of antisera to steroid hormones. In Proc. Workshop on Gonadotrophins and Gonadal Steroids, pp. 197-227. Eds P. G. Crossignoni \& V. H. T. James. Academic Press, New York.

Martinet, L., Legouis, J.J. \& Moret, B. (1970) Quelques observations sur la reproduction du lièvre Européen (Lepus europaeus Pallas) en captivité. Annls Biol. anim. Biochim. Biophys. 10, 195-202.

Mikhail, G., Noall, N.W. \& Allen, W.M. (1961) Progesterone levels in the rabbit ovarian vein blood throughout pregnancy. Endocrinology 69, 504-509. 
Morishige, W.K., Pepe, G.J. \& Rothchild, I. (1973) Serum luteinizing hormone, prolactin and progesterone levels during pregnancy in the rat. Endocrinology 92, 1527-1530.

Murr, S.M., Stabenfeldt, G.H., Bradford, G.E. \& Geschwind, I.I. (1974) Plasma progesterone during pregnancy in the mouse. Endocrinology 94, 12091211.

Olier, B. \& MONTET, P. (1972) Comment Créer et Conduire un Élevage de Lièvres. La Maison Rustique, Paris.

PePe, G.J. \& Rothchild, I. (1972) The effect of hypophysectomy on the 12th day of pregnancy on the serum progesterone level and the time of parturition in the rat. Endocrinology 91, 1380-1385.

PePe, G.J. \& RothChILd, I. (1974) A comparative study of serum progesterone levels in pregnancy and various types of pseudopregnancy in the rat. Endocrinology 95, 275-279.

Puger, A. (1966) Essai d'élevage en captivité étroite du lièvre commun, Lepus europaeus Pallas, 1778. Bull. Mus. Hist. Nat. Paris 38, 333-336.

Puget, A. (1970) Contribution à l'étude de l'élevage en captivité étroite de Lepus europaeus Pallas, 1778. Bull. Mus. Hist. Nat. Paris 42, 1325-1333.

RoBson, J.M. (1937) Maintenance of pregnancy and the luteal function in hypophysectomized rabbits. $J$. Physiol., Lond. 90, 145-166.

RoBson, J.M. (1940) Prolongation of pregnancy in hypophysectomized rabbits by progesterone and oestrogens. J. Physiol., Lond. 97, 517-524.

RYAN, K.J. (1973) Steroid hormones in mammalian pregnancy. In Handbook of Physiology, Section 7: Endocrinology, Vol. II : Female Reproductive System, part 2, Ch. 44, pp. 285-293. Ed. R. O. Greep. Am. Physiol. Soc., Washington, D.C.

SchwarTz, N.B. \& TAlleY, W.L. (1968) Daily measurement of pituitary $\mathrm{LH}$ content during pregnancy in the rat: do cyclic changes persist?J. Reprod. Fert. 15, $39-45$.

Spies, H.G., Hilliard, J. \& Sawyer, C.H. (1968) Maintenance of corpora lutea and pregnancy in hypophysectomized rabbits. Endocrinology 83, 354 367.

STAVY, M. (1976) Aspects of rearing and reproduction of the hare (Lepus europaeus syriacus). M.Sc. thesis, Tel-Aviv University, Israel.

Stavy, M., Terkel, J. \& Marder, U. (1978) Artificial insemination in the European hare (Lepus europaeus syriacus). Lab. Anim. Sci. (in press).

Thenius, E. (1975) Hares, rabbits and pikas. In Grzimek's Animal Life Encyclopedia, Vol. 12, Chapter 11, pp. 420 429. Ed. B. Grzimek. Von Nostrand Reinhold Co., New York,

Van Rees, G.P., Van Dieten, J.A.M.J., BiJleveld, E. \& Muller, E.R.A. (1968) Induction of ovulation during pseudopregnancy in the rat. Neuroendocrinology 3, 220-228.

VIRGO, B.B. \& Bellward, G.D. (1974) Serum progesterone levels in the pregnant and postpartum laboratory mouse. Endocrinology $95,1486-1490$.

Westman, A. \& Jackobsohn, D. (1937) Über oestrinwirkungen auf die corpus luteum-funktion. Acta obstet. gynec. scand. 17, 13-23.

Received 27 July 1977 